\title{
強塩基性溶媒中における $\boldsymbol{p}$-ニトロアニリンと \\ ニトロベンゼン誘導体の反応 ${ }^{122}$
}

(1975 年 7 月 3 日 受理)

飯田弘忠・山崎道雄・高橋一公・山田和 俊*

$p$-ニトロアニリン [1]は $t-\mathrm{BuOK}-\mathrm{HMPA}$ 中で解離して, $p$-ニトロフェニルアミドイオンとなり, ニトロベンゼン誘導体 $[2 \mathrm{a} \sim \mathrm{g}]$ に対して求核置換反応を行なう。この求核置換反応は置換基の置換と 水素原子の置換の二つの反応型にわけることがでさる。一般に, 水素原子の置換はいずれの場合にも起 こり，ニトロ基に対してパラ位またはオルト位の水素原子が置換される。置換基がメタ位にある場合に は置換基の置換はおきないが，オルト位またはパラ位にある場合には置換される。両方の反応がともに 起こる場合には, $t-\mathrm{BuOK}$ の量が少ない場合に置換基の置換が優先し, 多い場合に水素の置換が優先す る。また, 生成物の $p$-ニトロアニリノ基の位置および ESR の測定結果から反応機構についても考察し た。

\section{1 腥 言}

アニリン誘導体と八ロゲン化アリールとの龢触媒存在下での反 伈はUllmann 反伈として知られ，数多くの報告があるが，強篮 基性溶媒中での反応例は少ない。Normant ら゙はへキサメチルホ スホルアミド(以下 HMPA と略記する)-ナトリウムアミド中でア ニリンとブロモベンゼンを反応させてトリフェニルアミンをま た, Caubèred) はHMPA-テトラヒドロフランーナトリウムアミド 中で $N$-メチルアニリンとブロモベンゼンを反応させて $N$-ハチル ジフェニルアミンを,さらに, Bergstrom ら5)はナトリウムまた はカリウム液体アンモニア中でジフェニルアミンとニトロベン ゼンを反応させて 4-ニトロトリフェニルアミンを，それそれ生 成するとの報告例がある。

著者らは， $p$-ニトロアニリン〔1]がカリウム $t-$ ブトキシド(以 下 $t$-BuOK と略記する)-HMPA 中で容易に安定なアミドイオン となることを見いたした。そこで，このアミドイオンがニトロ基 などで活性化された芳香族化合物と求核置換反応を行なうものと 考え，[1]と種々の二トロベンゼン誘導体 [2a～g] との反応を 怏討した。その結果, 図式 1 に示すように，この反応では置換基 の置換と水素原子の置換の 2 種の反応型によって生じる生成物が 得られることがわかった。本反応条件下において，水素の置換は いずれの場合にあ起こり，ニトロ基に対してオルト位またはパラ 位の水素が直換される。置換基がメタ位にある場合には直換基の

1）この報文を“塩基触媒反応に関する研究(第 7 報)”とする.

2）前報(第 6 報), 高橋一公, 望月英明, 山田和俊, 飯田弘忠, 日化, $1975,1208$.

* 千葉大学工学部合成化学科, 280 千葉市弥生町

3) H. Normant, T. Cuvigny, Bull. Soc. Chim. Fr., 1965, 1866.

4) P. Caubère, ibid., 1967, 3446.

5) F. W. Bergstrom, I. M. Granara, V. Erickson, J. Org. Chem., 7, 98(1942).
置換は打きないが，オルト位またはパラ位にある場合には㯰換さ れる。な扣, 生成物の $p$-ニトロアニリノ基の位置和よび反応溶 液の ESR の測定絬果なとから，これらの反応の機構についても 䓅察した。

Scheme 1

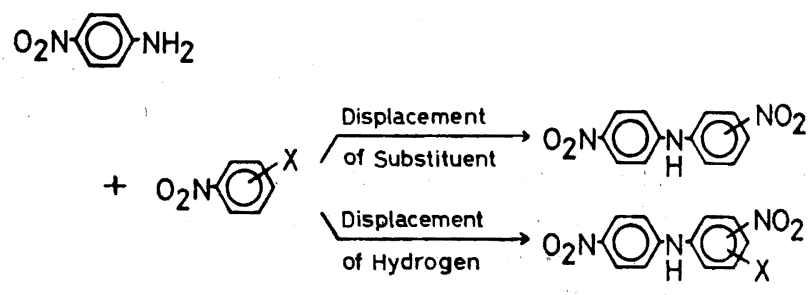

\section{2 実験結果亡考察}

[1]は $t$-BuOK-HMPA 中ですみやかに解離してアミドイオ ンとなるが， $t$-BuOK とそれ以上の反応を行なわないことから， アミドイオン源として好都合な試薬であることがわかった。

[1]と $[2 \mathrm{a} \sim \mathrm{g}]$ の反応は， [2 a g $]$ の置換基の有無，置換

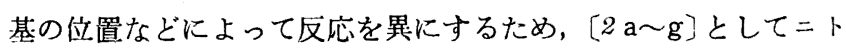
ロベンゼン， 0 -置換ニトロベンゼン， $m$-㯰換ニトロベンゼン, p-置換ニトロベンゼンの 4 種の組みを選び，それぞれについて検 行した。

$2.1 p$-ニトロアニリン $[1]$ とニトロベンゼン $[2 \mathrm{a}]$ の反応 乾燥窒素雾囲気下, $t$-BuOK-HMPA 中で [1]と [2a]の反 心を行なったところ，[2a]のオルト扰よびパラ位の水素原子と 置換した生成物が得られた(表 1 )。この反応は Bergstrom らら)の 実験に類似してはいるが，彼らはニトロベンゼンのパラ位の水素 がジフニルアミノ基と置換した化合物のみしか得ていない。こ れに対して, 著者らの実験ではオルト位执よびパラ位の水素の置 換した化合物，すなわち， $2,4^{\prime}$-ジニトロジフェニルアミン [3a] 拈よび $4,4^{\prime}$-ジニトロジフェニルアミン [3b]が得られた。しか 


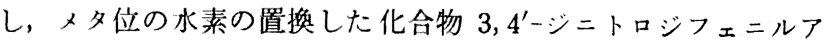
ミン [3c] は得られなかった。これはニトロペンゼンが求核試楽 に対してオルト扰よびパラ配向性を有するためである。

[1]の量を一定にして, 生成物の収率におよほす $[2 \mathrm{a}]$ と $t$ BuOK の添加量の影響を調べた(表 1)。いずれの場合にも，〔1] が回収されることを考慮すると，[3 a $] と[3 \mathrm{~b}]$ の収率の和が約 80\%にもなり，選択性がよいことを示している。 $t$-BuOK の量が 少ない場合には反応はあまり進行しないが，オルト位に比較して :ラ位の水素の置換が優先的に起こる。 $t$ - BuOK の量が増加する につれて, 逆に, オルト位の水素の盾換がパラ位の水素の置換よ り優先する傾向が見られる。また，塩基として $t$-BuOK のかわり にナトリウムアミドを用いると，Bergstrom らの結果と同様にパ ラ位の水素の置換のみが起こった。これはナトリウムアミドが HMPA にあまり溶解しないため, $t$-BuOKの量の少ない状態と同 じなるためと考えられる。カリウムを用いた場合にも，収率は わずかであるがパラ位の水素の置換のみが起こった。

$2.2 p$-ニトロアニリン $[1]$ と $p$-クロロニトロベンゼン $[2 \mathrm{~b}]$ または $p$-ブロモニトロベンゼン $[2 \mathrm{c}]$ との反応

[1]とpークロロニトロベンゼン $[2 \mathrm{~b}]$ との反応では，一般的

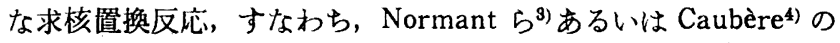
絬果と同様に，塩素が $p$-ニトロアニリノ基で置換された $4,4^{\prime}$-ジ ニトロシシフェニルアミン $[3 \mathrm{~b}]$ が得られるが, それとともに $[2 \mathrm{~b}]$ のニトロ基に対してオルト位の水素と置换した5ークロロ-2, $4^{\prime}$-ジ ニトロジフェニルアミン $[3 \mathrm{~d}]$ も生成することがわかった。この
よらに，置換しやすい直換基があるにもかかわらず，置換基が置 換されずに水素が置換される例はない。表 2 から明らかなよ5 に, $[3 \mathrm{~b}]$ と $[3 \mathrm{~d}]$ の収率の比は $t-\mathrm{BuOK}$ の添加量によって非常 に影響される。 $t$-BuOK の量が少ない場合には $p$-ニトロアニリノ 基による塩素の置換が優先し, 逆に, $t$-BuOK の量が増加するに つれて水素の置換が優先する傾向が見られる。また， $t$-BuOK を 一定にして $[2 \mathrm{~b}]$ の量を減少させると, [3 b ]と [3d]の収率 はともに減少する。これは〔1]の回収率が増加することから, $[2 \mathrm{~b}]$ が $t$-BuOK との反応で消費されてしまらためと思われる。

[1]とp-ブロモ二トロベンゼン $[2 \mathrm{c}]$ との反応も，[2b]と

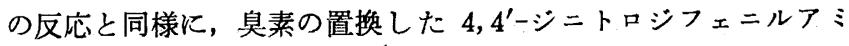
ソ [3b]と水素の置換した 5-ブロモ-2, $4^{\prime}$-ジニトロジフェニル アミン $[3 \mathrm{e}]$ が得られた。 $t$ - $\mathrm{BuOK}$ の添加量と臭素の置換と水素 の置換との関係は，ほとんど $[2 \mathrm{~b}]$ との反応の場合と同じである (表 2 )。

$2.3 p$-ニトロアニリン $[1]$ \& $m$-クロロニトロベンゼン $[2 \mathrm{~d}]$ または $\boldsymbol{m}$-ジニトロベンゼン $[2 \mathrm{e}]$ との反応

[1]と $m$-ク口ロニトロペンゼン $[2 \mathrm{~d}]$ の反応は, 塩素が $=ト$ 口基によって活性化されていないため, 塩素の置換した 3, $4^{\prime}$-ジ ニトロジフェニルアミン $[3 \mathrm{c}]$ は得られずに，4位の水素の置換

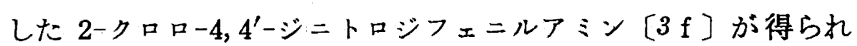
た。 4 位および 6 位の水素はニト口基に対して, それぞれパラお。 よびオルト位にあるため, 求核置換を受けやすいものと考えられ る。実際に，6位の水素の置換した4-クロロ-2, $4^{\prime}$-ジニトロジフ

Table 1 The reaction of $p$-nitroaniline [1] with nitrobenzene [ 2 a] in $t$-BuOK-HMPA system

\begin{tabular}{|c|c|c|c|c|c|c|c|}
\hline \multirow{2}{*}{ No. } & \multirow{2}{*}{$\begin{array}{c}{\left[\begin{array}{c}1] \\
(\mathrm{mmol})\end{array}\right.} \\
\end{array}$} & \multirow{2}{*}{$\begin{array}{c}{[2 \mathrm{a}]} \\
(\mathrm{mmol})\end{array}$} & \multirow{2}{*}{$\begin{array}{c}t-\mathrm{BuOK} \\
(\mathrm{mmol})\end{array}$} & \multicolumn{3}{|c|}{ Yield $(\%)$} & \multirow{2}{*}{$\begin{array}{l}\text { Molar ratio } \\
{[3 \mathrm{~b}]:[3 \mathrm{a}]}\end{array}$} \\
\hline & & & & {$[3 \mathrm{~b}]$} & {$[3 \mathrm{a}]$} & $\overline{[3 \mathrm{a}]+[3 \mathrm{~b}]}$ & \\
\hline 1 & 2 & 8 & 4 & 9 & 0 & 9 & $100: 0$ \\
\hline 2 & 2 & 8 & 8 & 53 & 21 & 74 & $72: 28$ \\
\hline 3 & 2 & 8 & 12 & 46 & 33 & 79 & $58: 42$ \\
\hline 4 & 2 & 8 & 16 & 29 & 36 & 65 & $45: 55$ \\
\hline 5 & 2 & 4 & 16 & 24 & 47 & 71 & $34: 66$ \\
\hline 6 & 2 & 2 & 16 & 16 & 37 & 53 & $30: 70$ \\
\hline 7 & 2 & 8 & $16^{a)}$ & 52 & 0 & 52 & \\
\hline 8 & 2 & 8 & $14^{b)}$ & 4 & 0 & 4 & \\
\hline
\end{tabular}

a) $\mathrm{NaNH}_{2}$, b) K, Reaction time ; $6 \mathrm{hr}$, Temp.; $20^{\circ} \mathrm{C}$.

3 a $]: 2,4^{\prime}$-Dinitrodiphenylamine. $[3 \mathrm{~b}]: 4,4^{\prime}$-Dinitrodiphenylamine.

Table 2 The reactions of $p$-nitroaniline [ 1$]$ with $p$-chloronitrobenzene $[2 \mathrm{~b}]$ or $p$-bromonitrobenzene $[2 \mathrm{c}]$ in $t$-BuOK-HMPA system

\begin{tabular}{|c|c|c|c|c|c|c|c|}
\hline \multirow{2}{*}{ No. } & \multirow{2}{*}{$\begin{array}{c}{[1]} \\
(\mathrm{mmol})\end{array}$} & \multirow{2}{*}{\multicolumn{2}{|c|}{$\underset{(\mathrm{mmol})}{[2 \mathrm{~b}] \text { or }[2 \mathrm{c}]}$}} & \multirow{2}{*}{$\begin{array}{c}t-\mathrm{BuOK} \\
(\mathrm{mmol})\end{array}$} & \multicolumn{2}{|c|}{ Yield $(\%)$} & \multirow{2}{*}{$\begin{array}{c}\text { Molar ratio of } \\
{[3 \mathrm{~b}]:[3 \mathrm{~d}] \text { or }[3 \mathrm{e}]}\end{array}$} \\
\hline & & & & & {$[3 \mathrm{~b}]$} & {$[3 d]$ or $[3 e]$} & \\
\hline 1 & 2 & {$[2 \mathrm{~b}]$} & 8 & 4 & 45 & {$[3 d] 1$} & $98: 2$ \\
\hline 2 & 2 & "I & 8 & 8 & 29 & " 9 & $76: 24$ \\
\hline 3 & 2 & " & 8 & 16 & 14 & " 35 & $29: 71$ \\
\hline 4 & 2 & $" \prime$ & 4 & 16 & 3 & 23 & $12: 88$ \\
\hline 5 & 2 & "I & 2 & 16 & 2 & " 11 & $15: 85$ \\
\hline 6 & 2 & {$[2 \mathrm{c}]$} & 4 & 4 & 44 & {$[3 \mathrm{e}] 0$} & $100: 0$ \\
\hline 7 & 2 & $"$ & 4 & 8 & 32 & " 21 & $60: 40$ \\
\hline 8 & 2 & $" \prime$ & 4 & 12 & 6 & 37 & $14: 86$ \\
\hline 9 & 2 & $\prime \prime$ & 4 & 16 & 5 & 35 & $13: 87$ \\
\hline
\end{tabular}

Reaction time : $6 \mathrm{hr}$, Temp.: $30^{\circ} \mathrm{C}$.

[3 d] : 5-Chloro-2, $4^{\prime}$-dinitrodiphenylamine.

[3 e ] : 5-Bromo-2, $4^{\prime}$-dinitrodiphenylamine. 


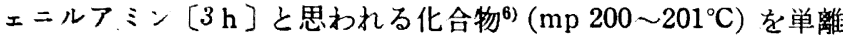
したが，その量が少なく，構造を確認するまでにいたらなかっ た。 $t$-BuOK と生成物 $[3 \mathrm{f}]$ の関係は，t-BuOK の量が多くて あ, 少なくても $[3 \mathrm{f}]$ の収率は减少した。 $t$-BuOK の量が少ない 場合には原料の回収が多いが， $t$-BuOK の量が多い場合には副反 沁物が多く，選択性が減少した。

[1]と $m$-ジニトロベンゼン [2e]の反応では 4 位の水素の置 換した 2,4,4'-トリニトロジフェニルアミン [3g]が生成する

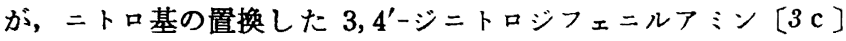
は得られなかった。 4 位の水素は一つのニトロ基に対してパラ位 にあり，もら一つの=トロ基に対してはオルト位にあるため非常 に求核置換を受けや寸いものと思われる。また，2 位の水素も両 方の二トロ基に対してオルト位にあるため，4位の水素と同様 に，求核置換を受けやすいはずであるが，これは二つの二ト口基 による立体障害のため, 置換しにくいのではないかと思われる。 ニトロ基の置換が起こらないのはニトロ基がほかのニトロ基に対 してメタ位にあるためと思われる。表 3 から明らかなように， $t$ BuOK の量が少ない場合に，反応はあまり進行しない。これは， [2e]が 2.5 の考察の項で述べるような機構により, ラジカルア

Table 3 The reactions of $p$-nitroaniline [1] with $m$ chloronitrobenzene $[2 \mathrm{~d}]$ or $m$-dinitrobenzene [2 e] in $t$-BuOK-HMPA system

\begin{tabular}{|c|c|c|c|c|c|c|}
\hline \multirow{2}{*}{$\frac{\text { No. }}{1}$} & \multirow{2}{*}{$\frac{\left(\begin{array}{c}{[1]} \\
\mathrm{mmol})\end{array}\right.}{2}$} & \multicolumn{2}{|c|}{$\underset{(\mathrm{mmol})}{[2 \mathrm{~d}] \text { or }[2 \mathrm{e}]}$} & \multirow{2}{*}{$\frac{\begin{array}{c}t-\mathrm{BuOK} \\
(\mathrm{mmol})\end{array}}{4}$} & \multicolumn{2}{|c|}{$\begin{array}{c}Y \text { ield }(\%) \\
{[3 \mathrm{f}] \text { or }[3 \mathrm{~g}]}\end{array}$} \\
\hline & & {$[2 \mathrm{~d}]$} & 4 & & {$[3 \mathrm{f}]$} & 23 \\
\hline 2 & 2 & 11 & 4 & 8 & 11 & 38 \\
\hline 3 & 2 & " & 4 & 12 & " & 23 \\
\hline 4 & 2 & "I & 4 & 16 & "I & 14 \\
\hline 5 & 2 & {$[2 \mathrm{e}]$} & 2 & 4 & {$[3 \mathrm{~g}]$} & 38 \\
\hline 6 & 2 & $"$ & 4 & 4 & $" \prime$ & 10 \\
\hline 7 & 2 & " & 4 & 8 & " & 82 \\
\hline 8 & 2 & " & 4 & 12 & $\prime \prime$ & 53 \\
\hline 9 & 2 & $" 1$ & 4 & 16 & $" \prime$ & 60 \\
\hline
\end{tabular}

Reaction time : $6 \mathrm{hr}$, Temp.: $30^{\circ} \mathrm{C}$.

[3f]: 2-Chloro-4, $4^{\prime}$-dinitrodiphenylamine. $[3 \mathrm{~g}]: 2,4,4^{\prime}$-Trinitrodiphenylamine.
ニオンになりやすいため, $t-\mathrm{BuOK} か ゙[2 \mathrm{e}]$ をラジカルアニオン にするのに消費され，〔1]のアニオン化に利用されないためで はないかと思われる。それゆえ，[2 e]の量を[1]と等モルに 減少させると水素の置換が増加する。 $t$-BuOK の量を增加すると $[3 \mathrm{~g}]$ の収率が增加するが， $t-\mathrm{BuOK}$ の量を大過剩にすると[2 e] と $t$ - BuOK との副反応が多くなり，[3 $\mathrm{g}]$ の収率は低下した。

$2.4 p$-ニトロアニリン〔1]とo-クロロニトロベンゼン $[2 \mathrm{f}]$ または o-ジニトロベンゼン $[2 \mathrm{~g}]$ の反応

[1]と0-クロロニトロベンゼン $[2 \mathrm{f}]$ との反応では, $[2 \mathrm{~b}]$

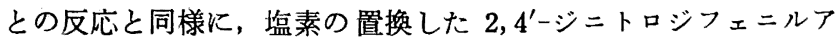

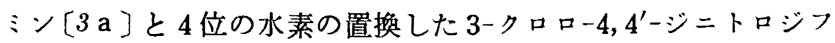
エニルアミン $[3 \mathrm{i}]$ が得られた。 6 位の水素もニトロ基に対して オルト位にあるため, 求核置換を受けやすいと考えられるが，実 際には 6 位の水素の置換した化合物は得られなかった。[2 b]の 場合と同様に， $t$-BuOK の量が少ない場合には塩素の置換が優先 し， $t$-BuOK の量が増加するにつれて水素の置换が優先する傾向 が見られる。

[1]とo-ジニトロベンゼン $[2 \mathrm{~g}]$ の反応でも, ニトロ基の置 換した $2,4^{\prime}$-ジニトロジフェニルアミン $[3 \mathrm{a}]$ と 4 位の水素の置 換した $3,4,4^{\prime}$-トリニトロジフェニルアミン $[3 \mathrm{j}]$ が得られたが， ニト口基の置換と水素の置換の比は $t$-BuOK の添加量に対して, 顕著な影響は見られなかった。

\section{5 反応機構についての考察}

[1]と $[2 \mathrm{~b}],[2 \mathrm{c}]$ および $[2 \mathrm{f}]$ との反応で, 置換基の置換 は $t$-BuOKの添加量が少ない場合に優先し, 水素の置換は $t$-BuOK の添加量が多い場合に優先することから考えて，この二つの反忘 は異なる機構で進行するものと思われる。そこで, 置換基の置換 と水素の置換の 2 種に分類して, それぞれの反応機構を考察し た。

2.5 .1 置換基の置換の反応機構 : $[1]$ と $p$-置換ニトロベンゼ

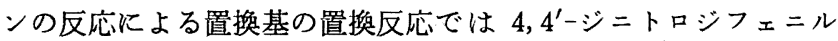
アミン $[3 \mathrm{~b}]$ のみが得られ， 0 -固換ニトロベンゼンの反応では $2,4^{\prime}$-ジニトロジフェニルアミン [3a]のみが得られたことから, 置換基の置換反応はベンザイン機構ではなく，図式 2 のように付

Table 4 The reactions of $p$-nitroaniline [1] with 0 -chloronitrobenzene $[2 \mathrm{f}]$ or 0 dinitrobenzene $[2 \mathrm{~g}]$ in $t-\mathrm{BuOK}-\mathrm{HMPA}$ system

\begin{tabular}{|c|c|c|c|c|c|c|c|}
\hline \multirow{2}{*}{ No. } & \multirow{2}{*}{$\begin{array}{l}{[1]} \\
(\mathrm{mmol})\end{array}$} & \multirow{2}{*}{\multicolumn{2}{|c|}{$\underset{(\mathrm{mmol})}{[2 \mathrm{f}]}$}} & \multirow{2}{*}{$\begin{array}{l}t-\mathrm{BuOK} \\
(\mathrm{mmol})\end{array}$} & \multicolumn{2}{|c|}{ Yield $(\%)$} & \multirow{2}{*}{$\begin{array}{l}\text { Molar ratio of } \\
{[3 \mathrm{a}]:[3 \mathrm{i}] \text { or }[3 \mathrm{j}}\end{array}$} \\
\hline & & & & & {$[3 \mathrm{a}]$} & {$[3 \mathrm{i}]$ or $[3 \mathrm{j}]$} & \\
\hline 1 & 2 & {$[2 \mathrm{f}]$} & 8 & 4 & 42 & [3i] 1 & $98: 2$ \\
\hline 2 & 2 & $\prime \prime$ & 8 & 8 & 48 & "I 17 & $74: 26$ \\
\hline 3 & 2 & $\prime \prime$ & 8 & 12 & 32 & " 27 & $54: 46$ \\
\hline 4 & 2 & $\prime \prime$ & 8 & 16 & 18 & "l 27 & $40: 60$ \\
\hline 5 & 2 & {$[2 \mathrm{~g}]$} & 4 & 4 & 16 & {$[3 \mathrm{j}] 10$} & $62: 38$ \\
\hline 6 & 2 & 11 & 4 & 8 & 45 & " 23 & $66: 34$ \\
\hline 7 & 2 & $\prime \prime$ & 4 & 12 & 31 & " 12 & $72: 28$ \\
\hline 8 & 2 & $\prime \prime$ & 4 & 16 & 8 & "I 4 & $67: 33$ \\
\hline
\end{tabular}

Reaction time $: 6 \mathrm{hr}$, Temp.: $30^{\circ} \mathrm{C}$.

[3 i ] : 3-Chloro-4, $4^{\prime}$-dinitrodiphenylamine.

[ 3 j] : 3, 4, 4'-Trinitrodiphenylamine.

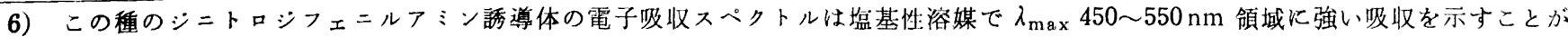

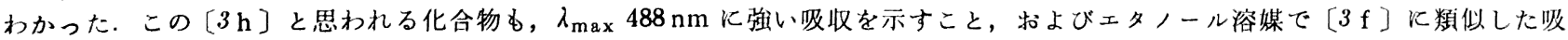
収を示すことから，その構造を推定した。 
Scheme 2 Displacement of Substituent

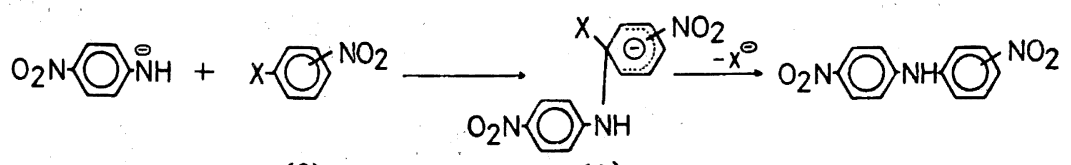

(2)

加一脱離の過程を通るものと思われる。ベンザインを中間体とす

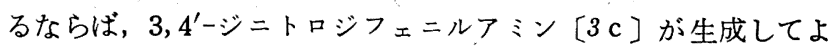
いはずであるが，いずれの場合にも，[3c]は得られなかった。

\section{5 .2 水素の置換の反応機構}

(1):[1]と [2a g] との反応の第一段階は, 図式 3 のよう に $p$-ニトロフェニルアミドイオンの $[2 \mathrm{a} \sim \mathrm{g}]$ への求核反応であ ってラジカル反応ではないと考える。その理由としては， $t$ - $\dot{\mathrm{B} u}$ ・ OK一HMPA 中の[1] からは ESR スペクトルでラジカルが検出 されなかったこと，[1]と[2a]との応でオルト位，パラ位 の水素の置換が起こり, メタ位の水素の置換生成物が得られなか ったこと，また，㯰換ニトロベンゼンとの反応でもパラ位または オルト位の水素の置換生成物のみが得られることがあげられる。 ラジカルが [2a]を攻撃するとすれば, ベンゼンを反応系中に存 在させることにより，ラジカルの攻撃を受け，4-ニトロジフェニ ルアミンを生成すると考えられる。さらに, ラジカルの二量化物 も得られるはずだが，いずれも，その存在を確認できなかった。

（2）：図式 3 の錯体 [B]：からの水素の引き抜きは，二トロベ ンゼン誘導体 [2 $\mathrm{a} \sim \mathrm{g}]$ による水素アニオンの引き抜きと, 電荷 移動によって生じたラジカル [C]からの [2a〜g]のラジカルア ニオソ [D]による水素ラジカルの引き抜きが考えられるが, 後 者の方が優先するものと考えられる。その理由としてつぎの点が あげられる。反応系中から ESR スペクトルにより, Stevenson7) が K-HMPA 中のニトロベンゼンから検出したのと同様のニトロ ベンゼンラジカルアニオンを確認できたこと。および, Bunnett
(A)
$ら^{8)}$ によって述べられているように, 錯体 [B] の水素原子はア ニオンとして脱離しにくいため, 水素原子が脱離するためには酸 化剤（本実験ではニトロペンゼン誘導体）の存在が必要であるこ とから，水素原子の脱離は錯体 [C] を経由するすのと考兄られ ること。また，[1]と[2d]の反応物から $3,3^{\prime}$-ジクロロアソキ シベンゼンを少量ではあるが単離確認でき，さらに，[2a]との 反応物から，ガスクロマトグラフィーでアゾキシベンゼンを少量 ながら確認できたことによる。ここで生じたアゾキシベンぜン誘 導体は電子受容体として作用したニトロペンゼン誘導体が還元さ れて，つぎの機構を経て得られたものと考えられる。すなわら， [D]は [C]から水素ラジカルを引き抜いて $[\mathrm{F}]$ となり， $[\mathrm{F}]$ からは置換ニトロソベンゼンを生じ, これが [F] のさらに還元 して生じた置換フェニルヒドロキシルアミンと縮合してアゾキシ ベンゼン誘導体を生じたるのと考える。

（３）：表 2 と表 3 で明らかなように, p-クロロニトロベンセン

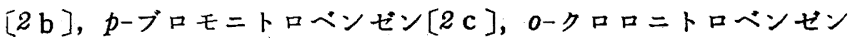
$[2 \mathrm{f}]$ では㯰換基の置換と水素の置換の両方が起こり, $t$-BuOK の濃度が高いほど水素の置換が進行しやすくなっている。これは $t$-BuOK の濃度の高いほど図式 4 の反応によってニトロベンゼン 誘導体のラジカルアニオン [D] が生じやすくなり, 図式 3 の [B]から[E]の生成が促進されるだめであると考えられる。

(4) : 表 1 の実験では $t$-BuOK の濃度の低い場合にはニトロへ ソゼンのオルト位の水素の置換体 [3a $]$ 少生成が困離となってい る。この理由については, 証拠はないが, 著者らはつぎのように

Scheme 3 Displacement of Hydrogen<smiles>[X]c1ccccc1NCc1ccc([N+](=O)[O-])cc1</smiles>

(2)

(B)<smiles>[X]c1cccc(N([O+])c2ccc([N+](=O)[O-])cc2)c1</smiles>

(2)

[C]<smiles>[X]c1ccc(Nc2ccc([N+](=O)[O-])cc2)cc1[N+](=O)[O-]</smiles>

[E]
[F]

Scheme 4

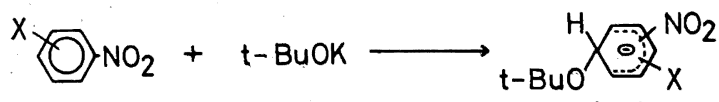

[G]

$\left[\mathrm{G}+\mathrm{X} \bigcirc \mathrm{NO}_{2}\right.$

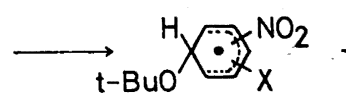

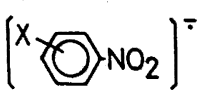

(D)
7) G. R. Stevenson, L. Echegoyen, J. Phys. Chem., 76, 1439 (1972).
8) J. F. Bunnett, R. E. Zahler, Chem. Revs., 49, 273(1951). 
Table 5 Physical data of reaction products

\begin{tabular}{|c|c|c|c|c|c|c|c|c|}
\hline \multirow{2}{*}{ Compd. } & \multirow{2}{*}{${ }_{\left({ }^{\circ} \mathrm{C}\right)}^{\mathrm{mp}}$} & \multirow{2}{*}{$\begin{array}{c}\mathrm{IR}(\mathrm{KBr}) \\
\left(\mathrm{cm}^{-1}\right) \\
\nu_{\mathrm{N}-\mathrm{H}}\end{array}$} & \multirow{2}{*}{$\begin{array}{c}\text { Mass } \\
\mathrm{M}^{+}\end{array}$} & \multirow{2}{*}{$\underset{\lambda_{\max }\left(\varepsilon \times 10^{-4}\right)}{U V}$} & \multirow{2}{*}{$\begin{array}{l}\text { NMR, } \delta \text { units } \\
\text { (DMSO) }\end{array}$} & \multicolumn{3}{|c|}{ Anal. [Calcd. (Found)] (\%) } \\
\hline & & & & & & $\mathrm{C}$ & $\mathrm{H}$ & $\mathrm{N}$ \\
\hline$[3 \mathrm{~d}]$ & $204 \sim 205$ & 3300 & 293 & $\begin{array}{l}245(3.25) \\
344(2.31) \\
398(2.39)\end{array}$ & $\begin{array}{l}9.71(1 \mathrm{H}, \mathrm{s}) \\
7.24 \sim 8.44(7 \mathrm{H}, \mathrm{m})\end{array}$ & $\begin{array}{c}49.08 \\
(49.04)\end{array}$ & $\begin{array}{c}2.75 \\
(2.66)\end{array}$ & $\begin{array}{c}14.31 \\
(14.19)\end{array}$ \\
\hline$[3 \mathrm{e}]$ & $205 \sim 206$ & 3300 & 337 & $\begin{array}{l}246(1.74) \\
288(0.86) \\
345(1.31) \\
400(1.37)\end{array}$ & $\begin{array}{l}\text { 9. } 49(1 \mathrm{H}, \mathrm{s}) \\
7.10 \sim 8.20(7 \mathrm{H}, \mathrm{m})\end{array}$ & $\begin{array}{c}42.63 \\
(42.88)\end{array}$ & $\begin{array}{l}2.39 \\
(2.33)\end{array}$ & $\begin{array}{c}12.43 \\
(12.38)\end{array}$ \\
\hline$[3 \mathrm{f}]$ & 224 & 3350 & 293 & $392(3.09)$ & $\begin{array}{l}\text { 9. } 17(1 \mathrm{H}, \mathrm{s}) \\
7.15 \sim 8.25(7 \mathrm{H}, \mathrm{m})\end{array}$ & $\begin{array}{c}49.08 \\
(49.36)\end{array}$ & $\begin{array}{l}2.75 \\
(2.68)\end{array}$ & $\begin{array}{c}14.31 \\
(14.14)\end{array}$ \\
\hline$[3 \mathrm{i}]$ & $233 \sim 234$ & 3320 & 293 & $\begin{array}{l}243(1.24) \\
395(3.68)\end{array}$ & $\begin{array}{l}\text { 9. } 78(1 \mathrm{H}, \mathrm{s}) \\
7.05 \sim 8.17(7 \mathrm{H}, \mathrm{m})\end{array}$ & $\begin{array}{c}49.08 \\
(49.35)\end{array}$ & $\begin{array}{l}2.75 \\
(2.57)\end{array}$ & $\begin{array}{c}14.31 \\
(14.04)\end{array}$ \\
\hline$[3 \mathrm{j}]$ & $284 \sim 285$ & 3350 & 304 & 398 (2.87) & $\begin{array}{l}10.05(1 \mathrm{H}, \mathrm{s}) \\
7.20 \sim 8.23(7 \mathrm{H}, \mathrm{m})\end{array}$ & $\begin{array}{c}47.38 \\
(47.45)\end{array}$ & $\begin{array}{l}2.65 \\
(2.56)\end{array}$ & $\begin{array}{c}18.42 \\
(18.10)\end{array}$ \\
\hline
\end{tabular}

考えている。 $t$-BuOK の添加量の変化は反応系の媒質を変えるた

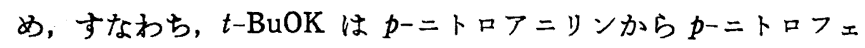
ニルアミドイオンを生成するのみならず, Meisenheimer 錯体 [B]から水素ラジカルを引き抜くニトロベンゼンラジカルアニ オン [D] の生成にも関与するため, 反応の律速段階が変わるこ とが十分考えられる。一般に，二トロ基に対して，オルト位はパ ラ位に比較してより強い感応効果の影響を受けているから，オル ト位の Meisenheimer 錯体 [B] の水素原子はパラ位の Meisenheimer 錯体の水素原子に比較して，水素ラジカルとしての脱離 を困難にしている。すなわち， $t$-BuOK の添加量が少ない場合， オルト体は [B] から [C] の生成が律速段階で，パラ体は [B] の生成が律速段階となっていると推定される。しかし， $t-\mathrm{BuOK}$ の添加量が多い場合, 水素ラジカルの引き抜き阂であるニトロへ ンゼンラジカルアニオン [D] の濃度も增大するため, 水素ラジ カルの引き抜きが容易になるから，オルト体もパラ体と同様に Meisenheimer 錯体 [B] の生成が律速段階となり, 表 1 のよ5 に, $t$-BuOK の添加量の増大とともに, オルト対パラの比が近似 的に 2 対 1 になったものと推定した。

\section{3 実験}

\section{1 試 薬}

HMPA は生石灰の存在下, 3 時間括だやかに煮沸して放冷後, 生石灰を沪別してから窒素䨌囲気下で減圧蒸留した。 $t$-BuOK は $t$-ブチルアルコールとカリウムとから 合成し, 未反応の $t$-ブチル アルコールを除くため, ガラスフィルターで吸引沪過し, ベンゼ ンでくり返し洗浄し, 乾燥して用いた。ニトロペンゼン誘導体は TLC を用いて市販品の純度を調べ，純粋なものはそのまま用い， 不純物の含まれるものについてはそれぞれ常法にしたがって精製 した。

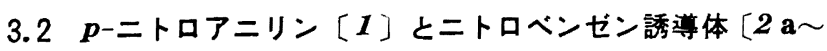

\section{g]との反応およひ生成物の定早}

乾燥窒素䨌囲気下, $100 \mathrm{~m} l$ の四つロフラスコに所定量の $t$ $\mathrm{BuOK}$ と HMPA $10 \mathrm{ml}$ を入れ，よくかきまぜながら $30^{\circ} \mathrm{C}$ に設定 する。約 10 分後, 〔1] $276 \mathrm{mg}(2 \mathrm{mmol})$ を $\mathrm{HMPA} 10 \mathrm{ml}$ に溶解 して加える。[1]を加えるとたたぢに $p$ ーニトロフェニルアミ
ドイオンを生成するために赤橙色になる。 $2 \sim 3$ 分以内に所定量 の〔2]を HMPA $10 \mathrm{~m} l$ に溶解して加え反応させる。[2]を加 えると, 生成するジフェニルアミン誘導体のアニオンおよび[2] のラジカルアニオンのために赤紫色から黒紫色となる。6 時間反 応させてから, 反応液を塩化アンモニウム水溶液に加えて反応を 停止させた。約 $100 \mathrm{~m} l$ のベンゼンで反応物を 3 回抽出し, 抽出 液を水洗し, 無水硫酸ナトリウムで乾燥した。ベンゼンを留去 し, 残留物の一部をベンゼン一酢酸エチルを展開溶媒とするシリ カゲルカラムクロマトグラフィーにかけて生成物を単離した。さ らに適当な溶媒で再結晶を行ない純度を高めた。

定量方法は上記の反応液のベンゼンを留去した残留物をアセ卜 ンに溶解させて $100 \mathrm{ml}$ にして, この溶液の $0.5 \mathrm{ml}$ を TLCにス ポットしてベンゼン一酢酸エチルまたはへキサンー酢酸エチルで展 開分離し, 生成物の部分を掻き取って, $50 \mathrm{ml}$ のエタノールで抽 出し, 生成物のモル吸光度から用いた [1] のモル数を基準にし て収率を計算によって求めた。

\section{3 反応生成物の物性}

反応生成物のちち, $[3 \mathrm{~d}],[3 \mathrm{e}],[3 \mathrm{f}],[3 \mathrm{i}],[3 \mathrm{j}]$ は文 献未知であったので, UV, IR, NMR, MS, 元素分析により構造 を確認した。物性值を表 5 に示す。

\subsection{ESR スペクトルの測定}

ESR スペクトルは HMPA 中で日本電子社製 JM-ME-3 X 型 ESR 装置を用いて測定した。試料はガス抜き後，測定部分をキ +ピラーにした $5 \mathrm{~mm}$ 径ガラス管に入れ，真空のまま封入した。 $t$-BuOK-HMPA 中の[1] からはラジカルが検出されなかった が, $t$-BuOK-HMPA 中の $[2 \mathrm{a}], t$-BuOK-HMPA 中の [1] [2a]，それに，K-HMPA 中の[1]と[2a]からはニトロベン ゼンラジカルアニオンが検出された。このスペクトルは Stevenson らが K-HMPA 中の=トロベンゼン [2a ロベンゼンラジカルアニオンのスペクトルとほぼ同じであった7)。

終りK, ESR 測定に御協力された千葉大学工学部印刷工学科 の山岡亜夫氏に感謝いたします。

（1974 年 4 月, 日本化学会第 30 春季年会；1975 年 4 月, 日本化 学会第 32 春季年会発表) 


\title{
The Reactions of $\boldsymbol{p}$-Nitroaniline with Nitrobenzene Derivatives in Strongly Basic Solution ${ }^{\dagger}$

\author{
Hirotada Iida, Michio Yamazaki, Kazumasa Takahashi
} \\ and Kazutoshi Yamada \\ Department of Synthetic Chemistry, Chiba University; Yayoi-cho, Chiba-shi 280 Japan
}

\begin{abstract}
$p$-Nitroaniline [ 1$]$ is ionized by $t$-BuOK in hexamethylphosphoramide (HMPA) to form $p$-nitrophenylamide ion, which gives rise to nucleophilic substitution with nitrobenzene derivatives $[2 \mathrm{a} \sim \mathrm{g}]$. We have found two types of the nucleophilic substitutions; the one with the substituent of $[2 \mathrm{a} \sim \mathrm{g}]$ and the other with the aromatic hydrogen atom. The latter, occurring in the ortho or para position to nitro group of $[2 \mathrm{a} \sim \mathrm{g}]$, was recognized in almost every reaction under various conditions. In the former type of the reaction, the meta substituent was not affected, but the ortho or para substituents were favorably displaced. Under such conditions as give rise to both types of the substitutions, the former type of the substitution was predominant when less amount of $t$-BuOK was used. On the other hand, the latter type of the substitution preferably proceeded when much amount of $t$-BuOK was used. The mechanisms of both types of the substitution are suggested from the structure of products and results of the measurement of ESR.
\end{abstract}

$\dagger$ Studies on the Base-catalyzed Reaction. VII. 